\title{
A PROJEKTALAPÚ SZERVEZETEK PIACI POZÍCIÓI A TIPIKUS PROJEKTPIACI SZEGMENSBEN AZ EMPIRIKUS VIZSGÁLATOK TÜKRÉBEN
}

A szerzó egy korábbi tanulmánya (Görög, 2013b) a projektteljesítési stratégiára vonatkozó projektvezetési szakirodalom alapján, tehát elméleti megfontolásokra alapozva, azonosította a projektpiac tipikus szegmensének alapvetó sajátosságait, valamint ugyanígy levezette az ebben a piaci szegmensben múködó projektalapú szervezetek piaci pozícióit alapvetően meghatározó tényezőket. A szerző ebben a tanulmányában az így feltárt sajátosságok és a piaci pozíciót determináló tényezők empirikus igazolására elvégzett kutatási eredményeit mutatja be.

Kulcsszavak: piaci pozíció a tipikus projektpiaci szegmensben, projektmarketing, tipikus projektügyletek sajátosságai

Statisztikai adatok (What are PMI Certifications?. n.a.; World Bank, 2005) szerint évenként a világviszonylatban megtermelt GDP mintegy 20\%-át projektek keretében költik el. A projektek döntő többsége úgynevezett külső projekt, vagyis a projekteket kezdeményező (projekttulajdonosi) szervezetek számára külső közremúködői (projektalapú) szervezetek teljesítik a projektfeladatokat. Ez utóbbi szervezetek számára a projektmarketing létfontosságú feladat, minthogy bevételük az elnyert projektfeladatok teljesítéséből származik. A projektmarketing egyfajta üzleti szervezetek közötti marketingtevékenység (Cova et al., 2002; Lecoeuvre-Soudain - Deshayes, 2006; Mandják - Veres, 1998; Skaates - Tikkanen, 2003), amelynek szükségessége a projektalapú vállalatok számára az ajánlat szerepéból adódik. Az ajánlatok alapvető szerepe kettős: a) egyrészt az ajánlattevő védelme, amennyiben az ajánlatot a benyújtott módon fogadják el (Marsh, 1981), b) másrészt annak demonstrálása, hogy elfogadás esetén az ajánlattevő teljesít (Görög, 2013a). Minthogy az ajánlat a másodikként említett szerepe révén közvetlenül a projektalapú szervezetek értékesítését segíti eló, így projektmarketing-vonatkozást is magában foglal, vagyis az ajánlat mint olyan indokolja a projektalapú szervezetek projektmarketing-tevékenységét. Ennek megfelelóen hangsúlyozza Turner et al. (2012), hogy a projektalapú szervezetekben a projektmarketing-tevékenységnek be kell ágyazódnia a projektvezetési folyamatba.
A projektmarketing-irodalom egyik sajátossága, hogy a publikációk döntő többsége a marketing területén múködő kutatók tollából származik, vagyis ezt a kérdéskört alapvetôen nem a projektvezetés kontextusában vizsgálják. A vonatkozó szakirodalom másik sajátossága (pl. Ahola et al., 2013; Cova et al., 2002; Davies et al., 2007; Kapletia - Probert, 2010; Kujala et al., 2013; Smyth - Lecoeuvre, 2015), hogy elsôsorban a projektpiac egy speciális szegmensére, a komplex rendszerek szállítására fókuszál, ahol a vevő (a projekttulajdonosi szervezet) valamilyen kormányzati szerv, miközben csak néhány potenciális rendszerszállító/rendszerintegrátor van a piacon. Ilyen körülmények között a potenciális szállítók mint projektalapú szervezetek által észlelt piaci pozíció a monopszónia. A szerzók többsége (pl. Jalkala et al., 2010; Lecoeuvre-Soudain et al., 2009) ezen a piacon a konstruktivista közelítésmódot (a vevői igény alakítása és a saját teljesítési feltételek elfogadtatása) és a kreatív (a már kialakított saját projektelképzelésen alapuló) ajánlat alkalmazását javasolja a projektalapú szervezetek számára. Ahola et al. (2013) álláspontja szerint ebben a szegmensben a piaci pozíció megtartása ugyanakkor feltételezi a technikai kompetencián alapuló funkcionális pozíció, valamint a vevővel és környezetével (milieu) kialakított viszony fenntartását. 
A komplex rendszerek vagy megoldások szállítása pénzértékben kifejezve a projektpiac jelentős szegmense, ugyanakkor az ilyen projektek számát tekintve kisméretú szegmens, ezért inkább atipikusnak tekinthetó. A projektalapú szervezetek többsége ettől eltérő piaci szegmensben múködik, ahol a projekteket kezdeményező projekttulajdonosi szervezetek jellemzően meghatározzák az elvárt projekteredményt és a teljesítés feltételrendszerét. A projektpiacnak ezt a szegmensét a projektek számossága alapján tipikusnak tekinthetjük, ahol a projektalapú szervezetek többnyire a tökéletes vagy oligopolisztikus versenynek megfelelö, esetleg a monopolisztikushoz közeli piaci pozíciót észlelnek.

A továbbiakban azzal a kiinduló feltevéssel élek, hogy a teljes projektpiac két szegmensre osztható, úgymint tipikus és atipikus szegmensek.

A tipikus szegmensben múködő projektalapú szervezetek az atipikus szegmenstől jelentősen különböző sajátosságok következtében nem alkalmazhatják sikeresen a konstruktivista közelítésmód alapján kialakított kreatív ajánlat eszközét. Helyette sokkal inkább a determinisztikus közelítésmódot (a lehetőségre való reagálás) kell, hogy kövessék, ami a tipikus projektpiaci szegmensben a projektmarketing sikeres alkalmazásához szükségessé teszi a várható piaci pozíciójuk feltárást.

Ebben a tanulmányban és az azt megalapozó empirikus kutatás fókuszában így azok a projektalapú szervezetek állnak, amelyek a projektpiac tipikus szegmensében múködnek (pl. ingatlanfejlesztés, infrastruktúra-fejlesztés, termelőkapacitás-bővítés stb.). A kutatás célja azoknak a tényezőknek az empirikus úton történő feltárása és igazolása, amelyek meghatározzák a projektalapú szervezetek piaci pozícióját a projektpiac tipikus szegmensében. A kutatás során az e vonatkozásban meghatározó koncepciókra, úgymint a projektalapú szervezet (a projektfeladat teljesítóje) és a projektteljesítési stratégia (a projektfeladat teljesítójének kiválasztási eszköze) fogalmára támaszkodunk.

A kutatási cél megvalósítása szükségessé teszi a következő specifikus feltevések megfogalmazását.

A tipikus projektpiaci tranzakciók sajátosságai levezethetók a projektteljesitési stratégia kérdéskörével foglalkozó projektvezetési szakirodalomból.

A projektalapú szervezetek által a tipikus projektpiaci tranzakciók során észlelt piaci pozíciót alapvetốen a projekttulajdonosi szervezet alkalmazott projektteljesitési stratégiája, azon belül is elsódlegesen az alkalmazott szerzódéstípus határozza meg.

A tanulmányt a következő struktúra szerint állítottam össze: a következő rész összegző áttekintést ad a szakirodalmi háttérről, ezt követően az empirikus kutatást és az alkalmazott kutatásmódszertant mutatom be, majd ismertetem az empirikus kutatás eredményeit, amit az eredményeket értékelô rész követ, végül pedig az elméleti következtetéseket és a gyakorlati lehetőségeket bemutató konklúziókat fogalmazom meg.

\section{Szakirodalmi összegzés}

A szerző egy korábbi - a projektmarketing kérdéskörét részben más aspektusból vizsgáló - cikke (Görög, 2013b) részletes áttekintést adott a projektmarketing nemzetközi szakirodalmáról, valamint a kapcsolódó projektvezetési koncepciókról, így itt csak egy összegző áttekintésre kerül sor, ami ugyanakkor hivatkozik az említett cikk megjelenését követố újabb publikációkra is.

A jelenlegi projektmarketing-irodalom, miközben a komplex rendszerek piacára fókuszál, két alapvető koncepción alapul. Ezek egyike a D-U-C modell (Mandják - Veres, 1998), ami a projektmarketing sajátosságait veszi alapul (D-discontinuity, U-uniqueness, C-complexity), a másik pedig a milieu (a projekttulajdonos mint vevó és környezete közötti kapcsolatrendszer) jelensége (Cova - Holstius, 1993; Cova et al., 1996; Cova - Hoskins, 1997; Cova et al., 2002; Lecoeuvre-Soudain et al., 2009). Ennek megfelelóen az irodalom a komplex rendszerek piacán múködő projektalapú szervezetek számára a milieu-vel való viszonyrendszeren, a konstruktivista közelítésmódon és a kreatív ajánlaton alapuló projektmarketing-megoldást propagálja (Cova et al., 2002; Cova et al., 2007; Jalkala et al., 2010; Lecoeuvre-Soudain - Deshayes, 2006; Lecoeuvre-Soudain et al., 2009). A szerzők által alapul vett piaci szegmens sajátossága, hogy a komplex rendszerek létrehozását kezdeményező projekttulajdonosi szervezet (rendszerint kormányzati szerv) nem a projekteredményt és a megvalósítás feltételrendszerét fogalmazza meg, hanem a projekteredmény révén elérni kívánt célt írja le. Jellemző esetnek tekintik a hivatkozott szerzők, hogy ezekhez a projektügyletekhez ellenvásárlási, visszavásárlási vagy barterügyletek kapcsolódnak.

Ugyanakkor egyes szerzők felhívják a figyelmet a referenciák (Salminen - Möller, 2006), a tárgyalási készség (Kujala et al., 2007), a tudáskezelés (Lehtimäki et al., 2009) és az értékalapú kommunikáció (Ballantyne et al., 2011; Fulford, 2013; Ryynänen et al., 2013) fontosságára. Más szerzők (Artto et al., 2008; Hadjukhani et al., 2012; Jalkala et al., 2010; Kujala et al., 2011, 2013; Ojansivu et al., 2013; Skaates - Tikkanen, 2003; Skaates et al., 2002; Tikkanen et al., 2007) pedig - a propagált marketing-közelítésmódok hatékonyságának növelésére - hangsúlyozzák a projektek közötti időszakokban a kapcsolatrendszer fenntartását, elsősorban a projekteredményhez kapcsolódó szervízszolgáltatások révén.

A projektmarketing aktív szereplője a projektalapú szervezet, ezért indokolt itt összegezni az erre vonatko- 
zó közelítésmódokat, és leszögezni azt, hogy a továbbiakban milyen tartalommal használjuk ezt a fogalmat. Néhányan a szerzók közül (Cattani et al., 2011; Hobday, 2000; Kujala et al., 2010; Sydow et al., 2004; Wikström et al., 2010) több értelemben is használatos és használható tartalommal ruházzák fel a projektalapú szervezet fogalmát. Vannak szerzők (Aubry et al., 2007; Gareis, 2005; Gareis - Stummer, 2008), akik azokat a szervezeteket tekintik projektalapon múködőnek, amelyek a stratégiai céljaik elérése érdekében definiált vezetői közelítésmód alapján kezdeményezik projektek teljesítését. Ugyanakkor más szerzők (Bredin, 2008; Turner - Keegan, 2001) csak az úgynevezett projekttulajdonosi szervezetek által kezdeményezett projektfeladatok teljesítését külső közremúködőként végző szervezeteket tekintik projektalapú szervezeteknek. A gyakorlatban is ez az értelmezés tekinthető a leginkább elterjedtnek, így a továbbiakban is ebben az értelemben használjuk a projektalapú szervezet fogalmát.

A kutatási céllal összefüggően megfogalmazott specifikus feltevések szükségessé teszik a projektteljesítési stratégia kérdéskörének az értelmezését is, ami egy külső projekt kapcsán a két alapvetően érintett projektszereplő (a kezdeményező projekttulajdonos és a teljesítést végző projektalapú) szervezet közötti felelősség- és kockázatmegosztás terjedelmében nyilvánul meg. Ez a felelősség- és kockázatmegosztás a kialakult és mára szokvánnyá vált szerződéstípusok és pénzügyi elszámolási módok segítségével valósítható meg (Görög, 2013a). A különböző szerződéstípusok és pénzügyi elszámolási módok különböző kombinációban történő alkalmazása a projekteredmény egészével, valamint a teljesítés időtartamával és költségeivel összefüggő felelősségek és kockázatok viselésének ugyancsak különböző kombinációit eredményezi. A projektteljesítési stratégiával szorosan összefüggő kérdéskör a versenyeztetés (a teljesítést végző külső közremúködő kiválasztása) és az előzetes minősítés (a potenciális külső közremúködők alkalmasságának értékelése) mint a projektteljesítési stratégia további eszközei (Bower, in: Bower, 2003c; El-Sawahi et al., 2007).

A másodikként megfogalmazott specifikus feltevés alapján a kutatási cél szempontjából a szerződéstípusoknak (tradicionális, kulcsrakész, menedzsment) van meghatározó szerepe. Ezzel összefüggésben célszerú itt kiemelni, hogy a projektteljesítési folyamat kisebb munkacsomagokra osztásán alapuló tradicionális szerződéstípus a projekttulajdonosi szervezetre allokálja a projekteredmény és a teljesítési időtartam egészével összefüggő felelősségek és kockázatok döntő többségét, így jelentős projektvezetési kapacitást igényel ebben a szervezetben. Ugyanakkor ez a szerződéstípus szélesebb versenyt indukál a potenciális külső közremúködői oldalon, vagyis egy projektalapú szervezet ebben az eset- ben a szinte tökéletes verseny körülményei között találja magát. Ez egyrészt az egyes munkacsomagok kisebb komplexitása és terjedelme révén, másrészt az előzetes minősítésben is megnyilvánuló alacsonyabb szintû projektvezetési képességre vonatkozó elvárás révén jön létre. Ezzel szemben a kulcsrakész szerződéstípus a külső közremúködôre allokálja a projekteredmény és a teljesítési időtartam egészével összefüggó felelősségek és kockázatok döntő többségét, így lényegesen kisebb projektvezetési kapacitást igényel a projekttulajdonosi szervezetben. Ez a szerződéstípus így a kulcsrakész külső közremúködőtől igényli a jelentôs projektvezetési kapacitást, miközben szúkíti a versenyt a potenciális külső közremúködői oldalon, vagyis egy projektalapú szervezet gyakran az oligopol, vagy nem egyszer a monopol közeli piacra jellemző verseny körülményei között találja magát. Ez egyrészt a projekteredmény munkatartalmának jelentős mértékú összetettsége és mérete révén, másrészt az előzetes minősítésben is megnyilvánuló magas szintú projektvezetési képességre vonatkozó elvárás révén jön létre. Összességében megállapítható, hogy a versenyeztetéshez kapcsolódó előzetes minősítésben a különböző szerződéstípusok az alkalmasság (technikai, pénzügyi, projektvezetési) más-más vonatkozásait teszik meghatározóvá. Itt kell megjegyezni, hogy minden komplex rendszer (pl. katonai légvédelmi rendszer) szállítója, per se, egy kulcsrakész külső közremúködő, noha a kulcsrakész szerződéstípus keretében létrehozott projekteredmények (pl. lakópark, vezetói információsrendszer stb.) közel sem mindegyike tekinthetó az előbbihez hasonló komplex rendszernek.

A projektteljesítési stratégiára vonatkozó projektvezetési szakirodalom alapján megfogalmazhatók a projektpiac tipikus szegmensére jellemző alapvető sajátosságok. Ezeket a szerző szintén részletesebben kifejtette egy korábbi, már említett cikkében (Görög, 2013b), így itt csak az alábbi vázlatos áttekintést adjuk:

- A tipikus projektügyleti tranzakciók üzleti szervezetek közötti tranzakciók, még kulcsrakész szerződéstípus esetén sem tartalmaznak ellenvásárlási, visszavásárlási vagy barterügyleteket. A projektvezetési szakirodalomban nem található ezekre való utalás.

- A projekteredmény létrehozatalát kezdeményező projekttulajdonosi szervezet meghatározza magát a projekteredményt és a teljesítés feltételrendszerét, amelyeket a versenyző projektalapú szervezetek adottságként fogadnak el (Bower, in: Bower, 2003a, 2033b; Bower - Smith, in: Smith, 1995; Lawson, in: Lawson et al., 1999; Smith, in: Smith, 1995; Turner, in: Turner, 2009). Alátámasztja ezt a projektpiac tipikus szegmensében múködố projekttulajdonosi szervezetek ajánlatrangsorolási kö- 
zelítésmódja is (Bower, in: Bower, 2003c; Gido Clements, 1999; Smith, in: Smith, 1995; Schwalbe, 2004; Watt et al., 2010).

- Az üzleti tranzakció tárgya az elvárt projekteredmény, ami azonban a teljesítésre vonatkozó ügylet létrejöttekor még - értelemszerúen - nem létezik. Ebből következốen a teljesítés olyan projektalapú szervezeteknek ítélhetô oda, amelyek az előzetes minősítés során bizonyították, hogy rendelkeznek a feltételek (projekttartalom, szerződéstípus, teljesítési feltételek) determinálta (technikai, pénzügyi és projektvezetési) képességekkel (Bower, in: Bower, 2003c; El-Sawahi et al., 2007; Smith, in: Smith, 1995).

- A projekttulajdonosi szervezetek rendszerint egy időben több projektet kezdeményeznek, amelyek teljesítéséhez különböző projektteljesítési stratégiát - így eltérô szerződéstípust - alkalmaznak (Görög, 2013a; Turner, in: Turner, 2009).

A projekttulajdonosi szervezet, hasonlóan minden, üzleti szervezetek közötti ügylethez, szervezeti vevő. Noha a beszerzési központ (Webster - Wind, 1972) szerepe a projektügylet sajátosságai miatt részben eltérhet a klasszikus megoldástól, magatartása meróben eltéró az úgynevezett milieu (Cova et al., 2002) magatartásától.

Ahogy a projekttulajdonosi szervezetek egyidejúleg több projektet is kezdeményeznek, amelyek mindegyike eltéró projektteljesítési stratégiát is alkalmazhat, a projektalapú szervezetek is több projekttulajdonosi szervezettel állhatnak kapcsolatban (előzetes minősítés, ajánlat) egyidejúleg. Ebből következően egy adott projektalapú szervezet a különböző projektügyletei kapcsán eltéró piaci pozíciót érzékelhet. Figyelembe véve a tipikus projektpiaci szegmensben az alkalmazásra kerülő különböző projektteljesítési stratégiák konzekvenciáit, valamint ennek a piaci szegmensnek az elóbbiekben áttekintett alapvetô sajátosságait, a következő konklúziót fogalmazhatjuk meg.

A tipikus projektpiaci szegmensben a projektalapú szervezetek által érzékelhetó piaci pozíciót elsôdlegesen a projekttulajdonosi szervezet projektteljesitési stratégiájában alkalmazott szerzódéstípus határozza meg.

A tanulmány a továbbiakban ennek a konklúziónak az empirikus igazolásához elvégzett kutatás eredményeit mutatja be.

\section{A kutatás és a kutatásmódszertan}

Az empirikus kutatás alapvetó célja annak megállapítása volt, hogy az a szakirodalmi alapon nyugvó következtetés, miszerint a tipikus projektpiaci szegmensben a projektalapú szervezetek által érzékelt piaci pozíciót elsődlegesen a projekttulajdonosi szervezetben alkalmazott szerződéstípus határozza meg, igazolható-e. Ez a kutatási cél szükségessé teszi annak empirikus igazolását is, hogy a tipikus projektpiaci ügyletek szakirodalomból leszúrt alapvető sajátosságai helytállóak-e, vagyis érzékelhetôek-e a gyakorlatban. A kutatási célok elérése érdekében a következő kutatási kérdéseket fogalmaztam meg.

Támogatják-e tapasztalati tények a tipikus projektpiaci szegmens ügyletei szakirodalomból leszürt alapvetố sajátosságainak gyakorlatban érzékelhetó megnyilvánulásait?

Támogatják-e tapasztalati tények azt a szakirodalomból levont következtetést, miszerint a tipikus projektpiaci szegmensben a projektalapú szervezetek által érzékelt piaci pozíciót a projekttulajdonosi szervezetben alkalmazott szerzódéstípus alapvetóen meghatározza?

Támogatják-e tapasztalati tények azt a szakirodalomból leszúrt megállapítást, miszerint a projektalapú szervezetek elözetes minösitése során az alkalmasság komponenseinek fontossága a projekttulajdonosi szervezetben alkalmazott szerzódéstípusnak megfelelóen változik?

A kutatási kérdésekre adandó válasz megalapozásához interjún alapuló kutatást végeztünk abból a közvetlen célból, hogy tapasztalati megerôsítést nyerjünk a következő kérdéskörökre vonatkozóan:

- az ellenvásárlási, visszavásárlási és barterügyletek alkalmazásának előfordulása,

- a kreatív ajánlat alkalmazásának lehetôsége a versenyben lévő projektalapú szervezetek számára,

- a projekttulajdonosi szervezet és a versenyben lévő projektalapú szervezetek szerepe az ajánlati szakaszban, különös tekintettel a létrehozandó projekteredmény és a teljesítési feltételrendszer megfogalmazására,

- a különféle szerződéstípusok alkalmazásának változása és a változó alkalmazásuk esetén az ajánlatot tevő projektalapú szervezetek számának változása,

- az előzetes minősítés szerepe és komponenseinek változó fontossága az alkalmazott szerződéstípus függvényében.

Az elvégzett empirikus kutatás az elózetesen kiválasztott projektalapú szervezetek projektmarketingben közremúködő munkatársaival készített interjúkon alapult annak érdekében, hogy a kutatási kérdésekre vonatkozó tapasztalatokat összegyújteni és értékelni lehessen. Ennek a kvalitatív kutatási módszernek az alkalmazását indokolttá teszi, hogy támogatja a feltáró jellegú kutatást (Yin, 2003), amihez félig strukturált 
interjúzást (Arksey - Knight, 1999) alkalmaztunk. Ez a kutatási módszer ugyanakkor támogatja egy lehetséges új látásmód kialakítását is, miközben illeszkedik a kutató episztemológiai kiindulópontjához (Creswell, 2003; Strauss - Corbin, 1998), ami egyrészt a konstruktivizmus (ötletek felszínre hozatala), másrészt pedig a kritikai realizmus (közös tanulás).

A kutatás során az egyes interjúkon túlmenően többfázisú közös értékelésre került sor a meghatározó kulcsinformátorokkal, ami egyrészt magában foglalta az egyes interjúk értékelésének tartalmi egybevetését, másrészt kétszeri alkalommal a kulcsinformátorokkal történő közös értékelést. Az egyes interjúk értékelésének tartalmi egybevetése során feltártuk az azonos projektre vonatkozó információk közötti esetleges ellentmondásokat, míg a kulcsinformátorokkal történő közös értékelés a feltárt ellentmondások feloldását eredményezte. Ezeknek a megoldásoknak a révén növelhetô a kutatási eredmények általánosíthatóságának a megbízhatósága.

Az interjúalanyok szervezeti hátterét adó projektalapú szervezetek kiválasztása a vonatkozó szakirodalom (Eisenhardt, 1989) ajánlásai alapján történt. Az erre vonatkozó előzetes feltárás során a következő megfontolásokat vettük figyelembe: a) a projektalapú szervezetek különböző szerzódéstípusok keretében teljesítik a projektfeladatokat, hogy érzékelhetó legyen a piaci pozíciók különbözősége, b) a projektalapú szervezetek különböző ágazatokban való múködése, hogy megalapozott legyen a megbízhatóság és az általánosíthatóság, c) megfelelő számú olyan szakember, akik az ajánlati és a projektmarketing-tevékenységben gyakorlottak, vagy ezekért a tevékenységekért vezetői felelősséggel tartoznak, hogy megfelelő méretú információforrás álljon rendelkezésre egy-egy projektalapú szervezetben, és d) a projektalapú szervezetek projekttulajdonosi partnerei üzleti környezetben múködố szervezetek legyenek, hogy biztosítva legyen az üzleti szervezetek közötti tranzakció esete. A kutatás során az elemzés egységét ezek a szervezetek, pontosabban ezek felhalmozott tapasztalatai képezték. A figyelembe vett projektalapú szervezetek, amelyekról az 1. táblázat ad áttekintést, többsége a hazai piac mellett aktív szerepet töltött be projektfeladatok teljesítőjeként Közép-Európában és a Közel-Keleten egyaránt.

Hasonlóan a kiválasztott projektalapú szervezetekhez, a projektjeiket kezdeményező projekttulajdonosi szervezetek is különböző ágazatokban múködnek, úgymint kereskedelem, olaj- és gázipar, infrastruktúra-fejlesztés, bankszektor, élelmiszeripar és gyógyszeripar.

A kiválasztott projektalapú szervezetekben az interjúalanyok kiválasztása a felhalmozott projektpiaci tapasztalataik alapján történt a következő szempontok alapján: a) minimum 3 év alkalmazás a jelenlegi projektalapú szervezetben. és b) minimum öt projekt, amelyben részt vett. Az interjúkat, amelyek több, mint öt hónapos időszakot igényeltek, rögzítettük, majd ezt követően került sor azok tartalmának kvalitatív elemzésére (Miles - Huberman, 1994). Az interjúalanyok kategóriánkénti jellemzőit a 2. táblázat foglalja össze.

\section{Az interjúk szervezeti hátterét biztosító projektalapú szervezetek fó jellemzői}

\begin{tabular}{|c|c|c|c|c|}
\hline \multirow{2}{*}{$\begin{array}{l}\text { Az ágazat, amiben a } \\
\text { projektalapú szervezet } \\
\text { múködik }\end{array}$} & $\begin{array}{c}\text { A projektek évi } \\
\text { átlagos száma }\end{array}$ & $\begin{array}{l}\text { Az ajánlatok évi } \\
\text { átlagos száma }\end{array}$ & $\begin{array}{c}\text { A munkacsomagok évi } \\
\text { átlagos száma }\end{array}$ & $\begin{array}{l}\text { Az ajánlatok évi } \\
\text { átlagos száma }\end{array}$ \\
\hline & \multicolumn{2}{|c|}{$\begin{array}{c}\text { kulcsrakész típusú szerződés } \\
\text { keretében }\end{array}$} & \multicolumn{2}{|c|}{ tradicionális szerződéstípus keretében } \\
\hline Ingatlanfejlesztés & $3-4$ & $5-6$ & $6-10$ & $20-30$ \\
\hline Csővezetékrendszer & $1-2$ & $2-4$ & $5-8$ & $15-20$ \\
\hline Infrastruktúra (autóút) & $1-2$ & $2-3$ & $3-5$ & $10-15$ \\
\hline Infrastruktúra (vasút) & $1-2$ & $2-4$ & $2-4$ & $8-10$ \\
\hline Acélszerkezet & $1-2$ & $2-4$ & $2-3$ & $8-10$ \\
\hline $\begin{array}{l}\text { Gyártórendszer } \\
\text { (élelmiszer) }\end{array}$ & $1-2$ & $3-4$ & $2-3$ & $5-10$ \\
\hline IT/IS rendszer & $3-5$ & $6-8$ & 0 & 0 \\
\hline Szervezetfejlesztés & $2-4$ & $4-6$ & 0 & 0 \\
\hline
\end{tabular}




\section{Az interjúalanyok alapvető sajátosságai}

\begin{tabular}{|l|c|c|}
\hline $\begin{array}{c}\text { Projektmarketingben tapasztalt } \\
\text { interjúalanyok }\end{array}$ & $\begin{array}{c}\text { Az adott projektalapú szervezet- } \\
\text { ben eltöltött évek száma }\end{array}$ & $\begin{array}{c}\text { A projektek száma, amelyekben } \\
\text { az interjúalanyok az adott szerve- } \\
\text { zetben részt vettek }\end{array}$ \\
\hline 3 vezérigazgató & $4-6$ & $8-11$ \\
\hline 3 projektigazgató & $5-8$ & $7-11$ \\
\hline 4 projektiroda-vezető & $5-7$ & $8-13$ \\
\hline 15 vezető projektmunkatárs & $5-10$ & $7-15$ \\
\hline
\end{tabular}

Az interjúalanyok között volt felső vezetô (három vezérigazgató), projektigazgató (három projektigazgató, akik vezetői felelósséggel tartoztak a vállalati projektportfólió teljesítéséért), négy projektiroda-vezető (kettő közülük felelősséggel tartozott a vállalati projektportfólió teljesítéséért, további kettő pedig a projekttámogatói feladatokat ellátó iroda vezetôje), továbbá vezetô projektmunkatárs (tizenöt munkatárs). Az interjúalanyok közül mindegyik legalább nyolc projektben vett részt a szakmai pályafutása során, és mindegyikőjük jelentős mértékú felhalmozott tapasztalati tudással rendelkezett különböző szerződéstípusok (elsősorban tradicionális és kulcsrakész) keretében teljesített projektfeladatok terén a jelenlegi projektalapú szervezetében. Az interjúk idôtartama 60 és 80 perc között változott, miközben néhány interjúalannyal két alkalommal is sor került a beszélgetésre.

Az interjúkból nyert információk egyértelmúvé és hitelessé tétele érdekében (Patton, 1987) különbözô dokumentumokat (ajánlati felhívások, ajánlatok, előminősítési dokumentációk) is áttekintettünk, miközben bizonyos projekttulajdonosi szervezetektól is megerősítést kértünk bizonyos információk hitelesítésére. Ugyancsak az egyes interjúkból nyert információk egyértelmúvé és hitelessé tétele érdekében került sor arra, hogy az ugyanazon projekttel kapcsolatosan a több interjúalanytól származó információkat folyamatosan egybevetettük. A kutatási eredmények általánosítása és annak megerósítése érdekében úgynevezett kulcsinformátorok bevonásával két workshopot rendeztünk. Közülük az elsőn (ami négyórás idôtartamú volt) sor került a kutatási eredmények bemutatására, megvitatására és az általánosítható eredmények megfogalmazására. A második workshop (ami 150 perces volt) a kutatási eredmények általánosításának finomítását és a végleges kutatási eredmények megfogalmazását eredményezte.

\section{A kutatás eredményei}

A tanulmánynak ez a része a következó csoportosításban mutatja be a kutatás eredményeit: a) a tipikus projektpiaci tranzakciók szakirodalomból leszúrt alapvető sajátosságainak helytállósága, b) a projektalapú szervezetek érzékelt piaci pozíciójában a szerző́déstípus szakirodalomból levont meghatározó szerepének helytállósága, és c) az előzetes minősítés szakirodalomból levont meghatározó szerepének helytállósága a projektalapú szervezetek projektmarketing-tevékenységében. Ezt követően a kutatás olyan eredményeit is bemutatom, amelyek elérését nem fogalmaztam meg a kutatás célkitűzései között, noha a kutatás, mintegy véletlenül, felszínre hozta azokat. Ezek olyan tényezők, amelyek a projektalapú szervezetek versenypozícióját alakítják a tipikus projektpiaci szegmensben.

\section{Az elsödleges kutatási eredmények}

A kulcsinformátorok bevonásával megtartott két workshop megerósítette a tipikus projektpiaci tranzakciók szakirodalomból leszûrt alapvetô sajátosságainak helytállóságát. Az interjúalanyok döntő többsége egyetértett a következőkben:

- Az üzleti szervezetek közötti projektügyletek során a tipikus projektpiaci szegmensben ellenvásárlási, visszavásárlási és barterügyletek alkalmazására nem kerül sor. Az egyik kulcsinformátor szavai szerint: „Több, mint tíz projektben vettem részt mióta ennél a cégnél dolgozom, de még sohasem tapasztaltam, hogy ilyen megoldások részét képezték volna egy projektügyletnek."

- A kreatív ajánlat alkalmazása csak kivételes esetben fordul eló, és ahogy azt az egyik, az IT/IS szektorban dolgozó interjúalany megfogalmazta: „Nagyon ritkán tapasztaltam a kreatív ajánlat 
alkalmazhatóságát, akkor is elsósorban olyan esetben, amikor a vállalatunk egy új IT-megoldást akart bevezetni a piacon." Az egyik vezérigazgató pedig egyértelmúen leszögezte, hogy „Mi sohasem tapasztaltunk semmilyen lehetóséget a kreatív ajánlat alkalmazására.'

- A projekttulajdonosi szervezetek részletesen meghatározzák az elvárt projekteredményt és a teljesítési feltételrendszert. Az egyik interjúalany megfogalmazása szerint: „Mielö́t ehhez a vállalathoz jöttem, jelentós mértékú tapasztalatra tettem szert különbözó projektügyletek terén az ingatlanfejlesztésben és az infrastruktúra-fejlesztésben, és mindannyiszor azt találtam, hogy a projekttulajdonosi szervezetek szigorúan megfogalmazzák a létrehozandó projekteredményt is, meg a teljesitési kondíciókat is. Ugyanezt tapasztalom a jelenlegi cégemnél is."

- Mind az elvárt projekteredményt, mind a teljesítés feltételrendszerét részletes leírják az ajánlati felhívásban. Az egyik kulcsinformátor állítása szerint: „Az ajánlati felhívás egy olyan kulcsfontosságú dokumentum, ami teljes egyértelmúséggel írja le nemcsak a létrehozandó projekteredményt, hanem a teljesités minden feltételét képezó körülményt is."

- A versenyben lévó projektalapú szervezetek elfogadják az ajánlati felhívásban részletezett teljesí- tési feltételeket. Mint ahogy az egyik interjúalany fogalmazott: „Az én tapasztalatom szerint azok az ajánlatok, amelyek nincsenek megfelelésben az ajánlati felhivással, kizárásra kerülnek az ajánlatértékelési folyamatból."

- A projekteredmény (vagy annak egy-egy része) létrehozására a projekttulajdonosi szervezetek versenyeztetést alkalmaznak, amelyhez hozzátartozik az előzetes minősítés is. Az egyik interjúalany szavaival: „A versenyeztetés alkalmazása a projektpiacnak ebben a szegmensében lényegében evidencia, ajánlatot pedig csak az elóminósítési folyamatban sikeres projektalapú szervezetek nyújthatnak be."

A tipikus projektpiaci tranzakciók alapvető sajátosságaira vonatkozó kutatási eredményeket a 3. táblázat foglalja össze.

Az egyetértési szint azt fejezi ki, hogy az interjúalanyok milyen hányadának a tapasztalata erősíti meg a tipikus projektpiaci tranzakciók szakirodalomból leszúrt alapvetô sajátosságainak gyakorlatban megnyilvánuló helytállóságát. Azok az informátorok, akik információsrendszer-projektekben és szervezetfejlesztési projektekben szereztek tapasztalatot, alacsonyabb egyetértési szintet mutatnak, mint azok, akik a többi ágazat projektjeivel foglalkoznak. Ebben a kétféle esetben az informátorok

\section{A tipikus projektügyletek sajátosságaira vonatkozó kutatási eredmények}

\begin{tabular}{|c|c|c|c|c|c|c|c|c|}
\hline \multirow{2}{*}{$\begin{array}{c}\text { Kutatási } \\
\text { eredmények }\end{array}$} & $\begin{array}{c}\text { Ingat- } \\
\text { lanfejl. }\end{array}$ & $\begin{array}{c}\text { Csóvezeték- } \\
\text { rendszer }\end{array}$ & $\begin{array}{c}\text { Infrastr. } \\
\text { fejl. } \\
\text { (autót) }\end{array}$ & $\begin{array}{c}\text { Infrastr. } \\
\text { fejl. } \\
\text { (vasút) }\end{array}$ & $\begin{array}{c}\text { Acél- } \\
\text { szerk. }\end{array}$ & $\begin{array}{c}\text { Gyár- } \\
\text { tó-rendsz. }\end{array}$ & $\begin{array}{c}\text { IT/IS } \\
\text { rendsz. }\end{array}$ & $\begin{array}{c}\text { Szerv. } \\
\text { fejl. }\end{array}$ \\
\hline Ellenügylet nincs & 100 & 100 & 100 & 100 & 100 & 100 & 100 & 100 \\
\hline $\begin{array}{c}\text { Kreatív ajánlat nem } \\
\text { alkalm. }\end{array}$ & 95 & 100 & 100 & 100 & 100 & 100 & 75 & 100 \\
\hline $\begin{array}{c}\text { Projekteredmény } \\
\text { és telj. felt. előre } \\
\text { rögzítettek }\end{array}$ & 100 & 100 & 100 & 100 & 100 & 100 & 65 & 50 \\
\hline $\begin{array}{c}\text { Részletes ajánlati } \\
\text { felhívás alkalma- } \\
\text { zása }\end{array}$ & 100 & 100 & 100 & 100 & 100 & 100 & 65 & 50 \\
\hline $\begin{array}{c}\text { A versenyzők } \\
\text { elfogadják a felté- } \\
\text { teleket }\end{array}$ & 100 & 100 & 100 & 100 & 100 & 100 & 80 & 70 \\
\hline $\begin{array}{c}\text { A nyertest verse- } \\
\text { nyeztetéssel vá- } \\
\text { lasztják ki }\end{array}$ & 100 & 100 & 100 & 100 & 100 & 100 & 100 & 100 \\
\hline
\end{tabular}


tapasztalatai azt mutatják, hogy néhányszor a projekttulajdonosi szervezet nem fogalmazza meg részleteiben a projekteredményt, csak a projekteredménnyel szembeni követelményeket rögzítik, valamint a teljesítés feltételrendszerét fogalmazzák meg részletesen. Ebből következően ilyen esetben kevésbé részletes ajánlati felhívást bocsátanak ki, ami egyfajta rugalmasságot biztosít a versenyben lévő projektalapú szervezetek számára, elsősorban a projekteredmény fizikai struktúrájára vonatkozóan. A projekteredmény kevésbé részletes megfogalmazásának ezekben az esetekben többnyire az az oka, hogy „ezekben a projekttulajdonosi szervezetekben hiányzik az ehhez szükséges szakmai felkészültség", ahogy azt az egyik interjúalany kifejtette.

A kulcsinformátorok a két workshop során szintén megerősítették, hogy a tipikus projektpiaci szegmensben a projekttulajdonosi szervezetek a különböző projektjeik esetében eltérô szerződéstípust alkalmaznak a projektteljesítési stratégiájukban, továbbá azt is, hogy az ajánlattevők száma az alkalmazott szerződéstípus függvényében változik. Ugyanígy szintén megerősítették az előzetes minősítés kiemelkedő szerepét a tipikus projektpiaci szegmensben. Az interjúalanyok döntő többsége egyetértett a következőkben:

A projekttulajdonosi szervezetek a különböző külső projektek teljesítéséhez eltérő szerződéstípust - döntôen tradicionális és kulcsrakész szerződéstípust - alkalmaznak a projektteljesítési stratégiában. Az egyik kulcsinformátor megfogalmazásában: „A menedzsment szerzódéstípus alkalmazása inkább kivételesnek tekinthetô."
A tipikus projektpiaci szegmensben az ajánlattevők száma döntő mértékben a projekttulajdonosi szervezetben alkalmazott szerződéstípus függ vényében változik. A záró workshop alkalmával az egyik kulcsinformátor ezt a következőképpen foglalta össze: „Általában véve megállapítható, hogy tradicionális szerződéstípus esetén az ajánlatadó projektalapú szervezetek száma tíz fölött van, miközben a kulcsrakész szerzódéstípus alkalmazásakor ez az érték többnyire öt alatti, de elófordul, hogy csak 2-3 ajánlattevó van."

A tipikus projektpiaci szegmensben az elózetes minősítés a versenyeztetési folyamat része, döntő szerepe van az ajánlatadás lehetôségében, és az előzetes minősítés értékelési rendszere összhangban van a projektteljesítési stratégia kívánalmaival. Az interjúalanyok lényegében egyöntetúen állították, hogy: „Az elözetes minösités a szükséges képességek szempontjából vagyis a technikai, pénzügyi és projektvezetési képességek szükséges arányában - meg kell, hogy feleljen (többek között) a projektteljesítési stratégiában alkalmazott szerzódéstípus követelményeinek." Szintén egyetértés volt abban is, hogy a sikeres ajánlati tevékenységben az előzetes minősítés döntő fontosságú, amit az egyik kulcsinformátor így fogalmazott meg: „, a sikeres elözetes minösités egyfajta felvételi vizsga a potenciálisan nyertes ajánlattevók klubjába."

A tipikus projektpiaci szegmensben a szerződéstípusok változó alkalmazása és az ajánlattevők változó száma közötti összefüggésre, valamint az elôzetes minősítés ajánlati folyamatban játszott kiemelkedő szerepére vonatkozó kutatási eredményeket a 4. táblázat foglalja össze.

\section{A szerződéstípusok változó használatára, az ajánlattevő́k változó számára és az előzetes minősítés szerepére vonatkozó kutatási eredmények}

\begin{tabular}{|c|c|c|c|c|c|c|c|c|}
\hline & \multicolumn{7}{|c|}{ Az interjúalanyok egyetértési szintje ágazatonként (\%) } \\
\cline { 2 - 9 } $\begin{array}{c}\text { Kutatási eredmények } \\
\text { Ingatl. fejl. }\end{array}$ & $\begin{array}{c}\text { Cső- } \\
\text { vez. } \\
\text { rendsz. }\end{array}$ & $\begin{array}{c}\text { Infrastr. } \\
\text { (autóút) }\end{array}$ & $\begin{array}{c}\text { Infrastr. } \\
\text { (vasút.) }\end{array}$ & $\begin{array}{c}\text { Acél- } \\
\text { szerk. }\end{array}$ & $\begin{array}{c}\text { Gyártó- } \\
\text { rendsz. }\end{array}$ & $\begin{array}{c}\text { IT/IS } \\
\text { rendsz. }\end{array}$ & $\begin{array}{c}\text { Szerve- } \\
\text { zetfejl. }\end{array}$ & \\
\hline $\begin{array}{c}\text { Különbözón szerz. típusok } \\
\text { (trad. és kulcsrakész.) } \\
\text { kerülnek alkalmazásra }\end{array}$ & 100 & 100 & 100 & 100 & 100 & 100 & 90 & 90 \\
\hline $\begin{array}{c}\text { Az ajánlat- } \\
\text { tevók szá- } \\
\text { ma a szerz. } \\
\text { tip. szerint } \\
\text { vált. }\end{array} \begin{array}{c}\text { esetében } \\
\text { kevesebb, } \\
\text { trad. sz. } \\
\text { esetében több }\end{array}$ & 100 & 100 & 100 & 100 & 100 & 100 & 100 & 100 \\
\hline $\begin{array}{c}\text { Az előzetes minősítés a } \\
\text { versenyeztetési folyamat } \\
\text { része }\end{array}$ & 100 & 100 & 100 & 100 & 100 & 100 & 100 & 100 \\
\hline $\begin{array}{c}\text { Az előzetes minősítés } \\
\text { összhangban van a szerzó- } \\
\text { déstíp. követelményeivel }\end{array}$ & 100 & 100 & 100 & 100 & 100 & 100 & 100 & 100 \\
\hline
\end{tabular}

\section{VEZETÉSTUDOMÁNY}


Az egyetértési szint itt egyrészt azt fejezi ki, hogy az interjúalanyok milyen hányadának a tapasztalata erósíti meg, hogy a tipikus projektpiaci szegmensben a projekttulajdonosi szervezetek különböző szerződéstípusokat alkalmaznak a projektteljesítési stratégiájukban, és így az ajánlattevők száma a szerződéstípus függvényében változik. Másrészt az egyetértési szint kifejezi azt, hogy az interjúalanyok milyen hányadának a tapasztalata erősíti meg az előzetes minősítés ajánlati folyamatban betöltött kiemelkedő szerepét a tipikus projektpiaci szegmensben. Azok az informátorok, akik információsrendszer-projektekben és szervezetfejlesztési projektekben szereztek tapasztalatot ez estben is enyhén alacsonyabb egyetértési szintet mutatnak a szerződéstípusok alkalmazásánál, mint azok, akik a többi ágazat projektjeivel foglalkoznak. Ebben a kétféle esetben az informátorok tapasztalatai azt mutatják, hogy néhányszor a projekttulajdonosi szervezet menedzsment szerződéstípust is alkalmaz. Az egyik interjúalany erre vonatkozó állítása szerint: „A menedzsment szerzódéstípus projektteljesitési stratégiában való alkalmazása tovább szúkíti az ajánlattevók számát, ilyen esetben a tapasztalataim szerint az ajánlattevók számának átlagos értéke kettő."

\section{További kutatási eredmények}

Noha eredendően nem volt a kutatási célkitúzések fókuszpontjában, ugyanakkor az interjúalanyok felszínre hoztak olyan tényezőket, amelyek nem magát a piaci pozíciót érintik, hanem egy adott piaci pozícióban a versenyben lévố projektalapú szervezet versenypozícióját befolyásolják a tipikus projektpiaci szegmensben. Meg kell azonban jegyezni, hogy ezek a tényezók a különböző projektek esetében eltérő fontosságúak, ahogy azt az informátorok is megerősítették.

Az így feltárt tényezők egyike a teljesítéshez szükséges különleges eróforrások (pl. speciális géppark) okozta hatás, amit ugyan a versenyben lévő projektalapú szervezet birtokol, de ami a versenyeztetés idején nincs a teljesítési helyszínen. A versenypozícióra gyakorolt hatás nagyságát ez esetben a földrajzi távolság mértéke határozza meg. Minél nagyobb ez a távolság, annál nagyobb a teljesítési helyszínre történő telepítés költsége, ami növeli az ajánlati árat. Minél nagyobb ez a költség, így annál magasabb az ajánlati ár, következésképpen annál gyengébb az érintett projektalapú szervezet versenypozíciója. Miközben léteznek olyan, versenyben lévő projektalapú szervezetek, amelyeknek az ilyen jellegú eróforrásai a teljesítési helyszín közelében vannak, így versenyelőnyt élvezhetnek az előbbiekkel szemben. Az ilyen jellegú erőforrások versenypozícióra gyakorolt hatását azok az interjúalanyok érzékelték, akik csővezeték-építési, infrastruktúra-fejlesztési és acélszerkezet-építési projektekben vettek részt. Egyet- értés volt közöttük abban, hogy „az ilyen erôforrások versenypozícióra gyakorolt hatása nem függ a szerzódéstípustól, így minden piaci pozíció esetén megnyilvánulhat" - ahogy az egyikük fogalmazott.

A projektalapú szervezetek versenypozícióját a tipikus projektpiaci szegmensben befolyásoló további tényezók közös sajátossága, hogy azok a projekttulajdonosi szervezethez vagy annak múködési környezetéhez köthetők. Ezek a tényezők általában az ajánlatok értékelésén és rangsorolásán keresztül fejtik ki a versenypozícióra gyakorolt hatásukat elsősorban olyankor, amikor a projekttulajdonosi szervezet kulcsrakész-szerződéstípuson alapuló projektteljesítési stratégiát alkalmaz. Ezek az interjúalanyok révén feltárt, és velük egyetértésben megfogalmazott tényezők magukban foglalják:

- a projekttulajdonosi szervezetben a projekteredmény révén elérendó stratégiai célt, valamint a projekteredmény érintettjeinek (pl. felhasználók, múködtetók stb.) várakozásait,

- a projekttulajdonosi szervezet, mint szervezeti vevő szervezeti struktúráját és kultúráját,

- a szélesebb értelemben vett technológiai kultúra projekttulajdonosi szervezetre és annak múködési környezetése jellemző szintjét,

- a projekttulajdonosi szervezetre és annak múködési környezetése jellemző szociális és kulturális (vallási értékek, szociális normák stb.) sajátosságokat.

A kulcsinformátorok bevonásával tartott workshopok az említett tényezők szerepéról a következő magyarázatban mutattak egyetértést.

Az ajánlati felhívás megfelelóen leírja ugyan az elvárt projekteredményt, de jellemzóen nem tárja fel a kiindulási alapot képező stratégiai célt. A projektalapú szervezetek ugyanakkor ajánlattevőként, különösen kulcsrakész szerepkörben, rendelkeznek bizonyos fokú szabadsággal a projekteredmény fizikai struktúrájának alakításában. A kiindulási alapot képezó stratégiai cél, valamint az érintettek várakozásainak ismeretében a versenyben lévő projektalapú szervezetek vonzóbb ajánlati tartalmat tudnak kialakítani, aminek segítségével javítani tudják versenypozíciójukat. A kulcsrakész szerepkörben lévő projektalapú szervezeteknek „az ajánlati szakaszban az elvárt projekteredmény mögé kell nézni", ahogy az egyik interjúalany fogalmazott.

A projekttulajdonosi szervezet egy szervezeti vevo, ahol különböző szerepkörben lévő munkatársak vesznek részt a döntési folyamatban, vagyis ez estben a legjobb ajánlatra vonatkozó döntés kialakításában. Minthogy a döntési folyamatban résztvevők szerepköre eltérő, így eltérô nézőpontok alapján viszonyulnak az ajánlatokhoz, ezért a döntési folyamat végeredményé- 
re gyakorolt hatásuk is eltérô. A döntési folyamatban résztvevők valós hatása azonban jelentős mértékben függ a projekttulajdonosi szervezet szervezeti struktúrájától és kultúrájától. Ahogy az egyik kulcsinformátor ezt megfogalmazta: „A célirányos projektmarketingnek fel kell tárnia a projekttulajdonosi szervezet struktúráját és szervezeti kultúráját annak érdekében, hogy erról az oldalról is megalapozza a minél versenyképesebb ajánlat kialakítását."

A projekttulajdonosi szervezetre és annak múködési környezetére jellemző, szélesebb értelemben vett technológiai kultúra figyelembevétele kiemelkedô jelentôséggel bír minden olyan esetben, amikor e vonatkozásban lényeges különbség van a versenyben lévő projektalapú szervezet és a projekttulajdonosi szervezet között. Így előfordulhat, hogy sem a projekttulajdonosi szervezetben, sem annak múködési környezetében nem áll rendelkezésre a projekteredmény javasolt fizikai struktúrájának használatához és múködtetéséhez szükséges technológiai kultúra. Az egyik interjúalany a következő megfogalmazásban foglalta össze erre vonatkozó tapasztalatát: „Figyelembe véve ezeket az esetleges különbségeket, egy projektalapú szervezet vonzóbb ajánlati tartalmat képes kialakitani, ami szintén hozzájárul a versenypozíció növeléséhez." Ezt a megállapítást különösen azok az interjúalanyok támogatták, akiknek jelentős mértékú nemzetközi tapasztalata volt különböző országokban múködő projekttulajdonosi szervezetekkel.

A projekttulajdonosi szervezetre és annak múködési környezetése jellemző szociális és kulturális sajátosságok, mint például a vallási értékek, a szociális normák stb. akkor válnak jelentôs, a versenypozíciót befolyásoló tényezővé, amikor ezekben a vonatkozásokban lényeges különbségek vannak a versenyben lévő projektalapú szervezet és a projekttulajdonosi szervezet között. Ezt a megállapítást is különösen azok az interjúalanyok támogatták, akiknek jelentős mértékú nemzetközi tapasztalata volt különböző szociális és kulturális közegben múködő projekttulajdonosi szervezetekkel.

\section{A kutatási eredmények értékelése}

$\mathrm{Az}$ empirikus kutatás eredményeinek értékelése a megfogalmazott kutatási kérdések alapján történik. Így először az elsődleges kutatási eredmények interpretálására kerül sor, majd ezt követi a további kutatási eredmények magyarázata.

Az első kutatási kérdés a tipikus projektpiaci szegmens ügyleteinek alapvetô sajátosságait érintette, az erre vonatkozó kutatási eredményeket pedig a 3. táblázat foglalta össze. Általánosságban megállapítható, hogy az interjúalanyok között erős egyetértés volt arra vonatkozóan, hogy a szakirodalomból leszúrt sajátosságok a tipikus projektpiaci szegmens valós környezeté- ben tapasztalható módon érzékelhetôek. Azok az informátorok, akik az ingatlanfejlesztési, csővezeték-építési, infrastruktúra-fejlesztési (autópálya és vasút), acélszerkezeti és termelőrendszer-projektekben dolgoznak, $100 \%$-os egyetértési szintet mutattak minden egyes tipikus projektügyleti sajátosságban. Így egyértelmúen megerősítették, hogy a tipikus projektügyleti tranzakciók esetében jellemzően: a) nincsenek ellenügyletek bevonva, b) kreatív ajánlat alkalmazására nem kerül sor, c) a projekttulajdonos részletesen megfogalmazza mind a létrehozandó projekteredményt, mind a teljesítés feltételrendszerét, d) részletes, az előbbi pontban foglaltakat tartalmazó ajánlati felhívást bocsát ki a projekttulajdonos, e) a versenyben lévő projektalapú szervezetek elfogadják az ajánlati felhívás kondícióit, f) a legjobb ajánlatot versenyeztetés révén választják ki.

Azonban meg kell jegyezni, hogy azok az interjúalanyok, akik információsrendszer-projektekben és szervezetfejlesztési projektekben dolgoznak, alacsonyabb egyetértési szintet mutattak a következő sajátosságokban: a) a projekttulajdonos részletesen megfogalmazza mind a létrehozandó projekteredményt, mind a teljesítés feltételrendszerét, b) részletes, az előbbi pontban foglaltakat tartalmazó ajánlati felhívást bocsát ki a projekttulajdonos, c) a versenyben lévő projektalapú szervezetek elfogadják az ajánlati felhívás kondícióit. A jelenség mögött meghúzódó okok a projekttulajdonosi szervezetben az adott projektekre vonatkozó ismeretek hiányában keresendők. Ezek a körülmények ugyanis nem teszik lehetôvé a részletes ajánlati felhívás kialakítását, aminek révén manőverezési lehetőség nyílik a versenyben lévő projektalapú szervezetek számára.

A második kutatási kérdés arra vonatkozott, hogy a projektalapú szervezetek által érzékelt piaci pozíciót a projekttulajdonosi szervezetben alkalmazott szerződéstípus alapvetóen meghatározza a projektpiac tipikus szegmensében, az erre vonatkozó kutatási eredményeket pedig a 4. táblázat felső része foglalta össze. Az interjúalanyok között erős egyetértés volt arra vonatkozóan, hogy a projektpiac tipikus szegmensében a projekttulajdonosi szervezetben alkalmazott projektteljesítési stratégia jellemzóen tradicionális vagy kulcsrakész szerződéstípuson alapul, miközben ezeknek a szerződéstípusoknak az alkalmazása projektről projektre változhat. Az interjúalanyok között erős egyetértés volt abban is, hogy tradicionális szerződéstípus alkalmazásakor a versenyben lévő projektalapú szervezetek száma lényegesen magasabb, mint kulcsrakész szerződéstípus alkalmazásakor. Ugyanakkor azok az interjúalanyok, akik információsrendszer-projektekben és szervezetfejlesztési projektekben dolgoznak, enyhén alacsonyabb egyetértési szintet mutattak a szerződéstípusok használatában. Összevetve a többi ágazatba tartozó projektekben tapasztalatot szerzett informáto- 
rokkal, tapasztalataik szerint bizonyos estekben megfigyelhették a menedzsment szerződéstípus alkalmazását is. Ezek a tapasztalok ugyanakkor egyértelmúen azt mutatták, hogy a menedzsment szerződéstípus alkalmazása, a kulcsrakész szerződéstípus alkalmazásához való viszonyításban is, jelentősen csökkenti a versenyben lévő projektalapú szervezetek, vagyis az ajánlattevők számát.

A harmadik kutatási kérdés arra vonatkozott, hogy a projektalapú szervezetek előzetes minősítése során az alkalmasság komponenseinek fontossága a projekttulajdonosi szervezetben alkalmazott szerződéstípusnak megfelelóen változik. Ezeket a kutatási eredményeket pedig a 4. táblázat alsó része foglalta össze, amelyek egyértelmúen $100 \%$-os egyetértési szintet mutatnak mindkét állításra vonatkozóan, vagyis megállapítható, hogy a) az előzetes minősítés a versenyeztetési folyamat részét képezi a tipikus projektpiaci szegmensben, b) az előzetes minősítés komponenseinek fontossága összhangban változik a projektteljesítési stratégiában alkalmazott szerződéstípus követelményeivel.

Összességében megállapítható, hogy az empirikus kutatási eredmények igazolják a) a tipikus projektügyleti tranzakciók szakirodalomból leszúrt alapvető sajátosságainak gyakorlati relevanciáját, b) a projekttulajdonosi szervezetek a projektjeik teljesítéséhez változó szerződéstípust alkalmaznak a projektteljesítési stratégiában, aminek megfelelően változik a versenyben lévő projektalapú szervezetek (ajánlattevők) száma, és c) az elózetes minősítés része az ajánlati folyamatnak, azonban a projektalapú szervezetek alkalmassági komponenseinek fontossága változik a szerződéstípusok alkalmazásának változásával együtt.

Nem szerepelt ugyan a kutatási célkitúzések között, azonban az interjúalanyok felszínre hoztak olyan tényezóket, amelyek egy adott piaci pozícióban a versenyben lévő projektalapú szervezet versenypozícióját befolyásolják a tipikus projektpiaci szegmensben. Az interjúalanyok tapasztalatai szerint ezek a tényezők magukban foglalják a) a teljesítésben szükséges speciális erőforrások és a teljesítési helyszín közötti földrajzi távolságot, és b) a projekttulajdonosi szervezet vagy annak múködési környezetére jellemző sajátosságokat, úgymint a projekt kiindulási alapját képezô stratégiai cél, szervezeti struktúra és szervezeti kultúra, a tágabb értelemben vett technológiai kultúra, valamint a szociális és kulturális sajátosságok. A kulcsinformátorok megerősítették, hogy ezek a tényezők ugyancsak hatást gyakorolnak a projektalapú szervezetek projektmarketing-tevékenységére.

\section{Következtetések}

A kutatási célkitúzés középpontjában azoknak a tényezőknek a feltárása állt, amelyek alapvetóen meg- határozzák a projektalapú szervezetek piaci pozícióját a projektpiac tipikus szegmensében. Az empirikus kutatás arra irányult, hogy a projektteljesítési stratégiával foglalkozó projektvezetési szakirodalom alapján azonosítható ilyen tényezők relevanciájához empirikus igazolással szolgáljon. Az elért kutatási eredmények egyaránt lehetőséget nyújtanak mind elméleti következtetések, mind pedig a gyakorlatban is alkalmazható következtetések megfogalmazására.

$\mathrm{Az}$ elmélethez való hozzájárulást eredményező egyik ilyen következtetés maga az, hogy a projektpiac egésze két alapvető szegmensre osztható. Ezek egyike az úgynevezett atipikus szegmens, amely a komplex rendszerek szállításának piacát foglalja magában. Az erre jellemző sajátosságoknak megfelelően ebben a piaci szegmensben a versenyben lévó projektalapú szervezetek a monopszónia mint piaci pozíció jelenségével szembesülnek. Ebben a piaci szegmensben a jelenlegi projektmarketing-szakirodalomban propagált projektmarketing-eszközök (pl. konstruktivista közelítésmód, kreatív ajánlat, a milieu-vel való viszonyrendszer) eredményesen alkalmazható. A projektpiac másik szegmense az úgynevezett tipikus szegmens. Az erre jellemző sajátosságoknak megfelelóen ebben a szegmensben, ahogy azt ez a tanulmány is igazolta, a projektalapú szervezetek nem tudják alkalmazni azokat a projektmarketing-eszközöket, amelyeket az irodalom az atipikus szegmensben múködő projektalapú szervezetek számára ajánl.

Az elmélethez való hozzájárulás egy további eredménye annak a tényezónek az azonosítása, ami alapvetően meghatározza a tipikus projektpiaci szegmensben múködő projektalapú szervezetek által érzékelhető piaci pozíciót. Ez az alapvető tényező a projektteljesítési stratégiában alkalmazott szerzódéstípus. A projekttulajdonosi szervezetek a különböző projektjeik teljesítéséhez eltérő szerződéstípust alkalmaznak, aminek következtében a projektalapú szervezetek által érzékelt piaci pozíció projektról projektre, és projekttulajdonosról projekttulajdonosra változhat. A különböző szerződéstípusok alkalmazása eltérő számú ajánlattevőt, vagyis eltérô számú versenyben lévő projektalapú szervezetet eredményez. Amikor tradicionális szerződéstípust alkalmaznak, akkor az előzetes minősítést szerzett projektalapú szervezetek száma lényegesen magasabb, ami lényegében a tökéletes versenynek megfelelő piaci pozíciót biztosít a versenyben lévő ajánlattevő́k számára. A kulcsrakész szerzódéstípus alkalmazása ugyanakkor néhányra csökkenti az előzetes minősítést szerzett projektalapú szervezetek számát, így azok ebben az esetben az oligopólium vagy a monopóliumhoz közeli piaci pozícióban találják magukat. Általánosságban megállapítható, hogy a szerződéstípusok változó alkalmazásával együtt változik az előzetes minősítést 
szerzett projektalapú szervezetek száma, és mindezzel együtt változik a tipikus projektpiaci szegmensben a projektalapú szervezetek által érzékelt piaci pozíció.

Az elmélethez való hozzájárulás harmadik eredménye az előzetes minősítés tipikus projektpiaci szegmensben meglévő fontosságának feltárása. A projektteljesítési stratégiában a szerződéstípusok változó alkalmazása a projektalapú szervezetek előzetes minősítése során értékelt alkalmasság komponenseinek (technikai, pénzügyi, projektvezetési) változó fontosságát követeli meg. Minthogy az elvárt projekteredmény az ügylet létrejöttekor még nem létezik, így a projektfeladat teljesítése csak olyan projektalapú szervezet számára kerülhet odaítélésre, amelyik a szükséges kombinációban rendelkezik a teljesítéshez szükséges képességekkel. Ennek megfelelóen a projektpiac tipikus szegmensében az előzetes minősítés projektmarketingben betöltött szerepe kiemelkedő fontosságú. Ahogy az egyik kulcsinformátor fogalmazott: „tapasztalatom szerint ajánlatot csak elózetes minösitést szerzett vállalat nyújthat be ezen a piacon".

A kutatási eredmények az elmélethez való hozzájárulás mellett a gyakorlatban is alkalmazható következtetések megfogalmazására is lehetőséget teremtenek, amelyek az alábbiakat foglalják magukban:

- A tipikus projektpiaci szegmensben múködó projektalapú szervezetek projektről projektre értékelhetik és elórevetíthetik várható piaci pozíciójukat annak érdekében, hogy megalapozott döntést hozzanak az ajánlati folyamatban való részvételükról. - A tipikus projektpiaci szegmensben múködő projektalapú szervezetek projektről projektre célirányosabb előzetes minősítésre vonatkozó dokumentációt, úgyis mint projektmarketing-eszközt, állíthatnak össze, amivel növelni tudják nyerési esélyüket.

- A tipikus projektpiaci szegmensben múködő projektalapú szervezetek célirányosabb elemzést tudnak végezni az ajánlati szakaszban nemcsak az elvárt projekteredményre és a teljesítési feltételrendszerre vonatkozóan, hanem a projekttulajdonosi szervezetre mint szervezeti vevőre vonatkozóan is.

- A tipikus projektpiaci szegmensben kulcsrakész szerepkörben múködő projektalapú szervezetek az ajánlati szakaszban értékelhetik a versenypozíciójukat alakító tényezőket, így versenyképesebb ajánlat kialakítását tudják megalapozni.

A szerző reméli, hogy az itt bemutatott kutatási eredmények lehetôséget teremtenek a projektpiac tipikus szegmensében múködő projektalapú szervezetek célirányosabb és így eredményesebb projektmarketing-tevékenységének kialakításához.

\section{Lehetséges korlátok}

Az empirikus kutatási eredmények általánosítása 8 , különböző ágazatban múködő projektalapú szervezetben dolgozó 25 interjúalany felhalmozott tapasztalati tudásán alapul. Ezért a kutatási eredmények gyakorlati alkalmazása előtt célszerú az adott konkrét projektügyleti kontextus alapos értékelése. Ugyanakkor egy nagyobb minta alkalmazása további finomítást eredményezhet a kutatási eredmények gyakorlati alkalmazási lehetőségeit illetően. Így a további lehetséges kutatások magukban foglalhatják egyrészt egy ágazati értelemben szélesebb mintán alapuló kutatást, illetve a tipikus projektpiaci szegmensben múködő projektalapú szervezetek projektmarketing-gyakorlatának esetelemzéseken alapuló mélyebb elemzését.

\section{Felhasznált irodalom}

Ahola, T. - Kujala, J. - Laaksonen, T. - Aaltonen, K. (2013): Constructing the market position of a project-based firm. International Journal of Project Management, 31: p. 355-365.

Arksey, H. - Knight, P. (1999): Interviewing for social scientists. London: Sage

Artto, K. - Wikström, K. - Hellström, M. - Kujala, J. (2008): Impact of services on project business. International Journal of Project Management, 26: p. 497-508.

Aubry, M. - Hobbs, B. - Thuillier, D. (2007): A new framework for understanding organisational project management through the PMO. International Journal of Project Management, 25: p. 328-336.

Ballantyne, D. - Frow, P. - Varey, R. J. - Payne, A. (2011): Value propositions as communication practice: Taking a wider view. Industrial Marketing Management, 40(2): p. 202-210.

Bower, D. (2003a): The role of procurement in the construction industry. in: Bower, D. (ed.): Management of Procurement. London: Thomas Telford

Bower, D. (2003b): Contract strategy. in: Bower, D. (ed.): Management of Procurement. London: Thomas Telford

Bower, D. (2003c): Contractor selection, contract award and construction law in the UK. in: Bower, D. (ed.): Management of Procurement. London: Thomas Telford

Bower, D. - Smith, N. J. (1995): Tender Procedures and Contract Policy. in: Smith, N. J. (ed.): Engineering Project Management. London: Blackwell Science

Bredin, K. (2008): People capability of project-based organisations: A conceptual framework. International Journal of Project Management, 26: p. 566576. 
Cattani, G. - Ferriani, S. - Frederiksen, L. - Täube, F. (2011): Project-Based Organizing and Strategic Management: A Long-Term Research Agenda on Organizational Form. Bingley: Emerald Group

Cova, B. - Holstius, K. (1993): How to create competitive advantage in project business. Journal of Marketing Management, 9(2): p. 105-121.

Cova, B. - Mazett, F. - Salle, R. (1996): Milieu as a pertinent unit of analysis in project marketing. International Business Review, 5(6): p. 647-664.

Cova, B. - Hoskins, S. (1997): A twin-track networking approach to project marketing. European Management Journal, 15(5): p. 546-556.

Cova, B. - Ghauri, P. - Salle, R. (2002): Project Marketing: Beyond Competitive Bidding. Chichester: John Wiley \& Sons

Cova, B. - Mazet, F. - Salle, R. (2007): Introduction to the IMM special issue on 'project marketing and the marketing of solutions' a comprehensive approach to project marketing and the marketing of solutions. Industrial Marketing Management, 36(2): p. 168146.

Creswell, J. W. (2003): Qualitative, Quantitative, and Mixed Methods Approaches. London: Sage

Davies, A. - Brady, T. - Hobday, M. (2007): Organizing for solutions: Systems seller vs. systems integrator. Industrial Marketing Management, 36(2): p. 183-193.

Eisenhardt, K. M. (1989): Building theories from case study research. Academy of Management Review, 14: p. 532-550.

El-Sawahi, N. - Eaton, D. - Rustom, R. (2007): Contractor pre-qualification model: State-of-the-art. International Journal of Project Management, 25: p. 465-474.

Fulford, $R$. (2013): The Sales Process of Information Systems: Implications for Project Execution and Business benefits. Project Management Journal, 44(5): p. 89-99.

Gareis, $R$. (2005): Happy Projects! Vienna: MANZ

Gareis, R. - Stummer, M. (2008): Process \& Projects. Wien: MANZ

Gido, J. - Clements, J. P. (1999): Successful project management. Cincinnati, Ohio: International Thomson

Görög, M. (2013a): A Strategic Oriented Implementation of Projects. Newtown Square, PA.: PMI

Görög, M. (2013b): A projektalapú szervezetek projektmarketing-tevékenységének sajátos kontextusa. Vezetéstudomány, 44 (11): p. 2-15.

Hadjukhani, A. - Lindh, C. - Thilenius, P. (2012): The impact of discontinuity on firms' business relationship behaviour. European Business Review, 5(3): p. 319-336.
Hobday, M. (2000): The project-based organisation: an ideal form for managing complex products and systems? Research Policy, 29: p. 871-893.

Jalkala, A. - Cova, B. - Salle, R. - Salminen, R. T. (2010): Changing project business orientations: Towards a new logic of project marketing. European Management Journal, 28(2): p. 124-138.

Kapletia, D . - Probert, D. (2010): Migrating from products to solutions: An exploration of system support in the UK defense industry. Industrial Marketing Management, 39(4): p. 582-592.

Kujala, J. - Murtoaro, J. - Artto, K. (2007): A negotiation approach to project sales and implementation. Project Management Journal, 38(4): p. 33-44.

Kujala, S. - Artto, K. - Aaltonen, P. - Turkulainen, $V$. (2010): Business models in project-based firms - Towards a typology of solution-specific business models. International Journal of Project Management, 28: p. 96-106.

Kujala, S. - Kujala, J. - Aaltonen, P. - Artto, K. - Turkulainen, V. - Wikström, K. (2011): Factors influencing the choice of a solution-specific business model. International Journal of Project Management, 29: p. 960-970.

Kujala, J. - Ahola, T. - Huikuri, S. (2013): Use of services to support the business of a project-based firm. International Journal of Project Management, 31: p. 177-189.

Lawson, G. (1999): Project strategy and organization. in: Lawson, G. - Wearne, S. - Iles-Smith, P. (eds.): Project management for the process industries. Rugby, Warwickshire: IChem

Lecoeuvre-Soudain, L. - Deshayes, P. (2006): From marketing to project management. Project Management Journal, 37(5): p. 103-112.

Lecoeuvre-Soudain, L. - Deshayes, P. - Tikkanen, H. (2009): Positioning of the Stakeholders in the Interaction Project Management - Project Marketing: A Case of a Coconstructed Industrial Project. Project Management Journal, 40(3): p. 34-46.

Lehtimäki, T. - Simula, H. - Salo, J. (2009): Applying knowledge management to project marketing in a demanding technology transfer project: Convincing the industrial customer over the knowledge gap. Industrial Marketing Management, 38(2): p. 228-236.

Mandják, T. - Veres, Z. (1998): The D-U-C Model and the stages of the project marketing process. in: Halinen, A., Nummela, N. (eds.): Proceedings of the $14^{\text {th }}$ IMP annual conference. Turku, Finland: p. 471-490.

Marsh, P.D. V. (1981): Contracting for Engineering and Construction Projects. Aldershot: Gower

Miles, M. B. - Huberman, A. M. (1994): Qualitative data analysis. Thousand Oaks, CA.: Sage Publications 
Ojansivu, I. - Alajoutsijàrvi, K. - Salo, J. (2013): The development of post-project buyer-seller interaction in service-intensive projects. Industrial Marketing Management, 42: p. 1318-1327.

Patton, M. Q. (1987): Qualitative evaluation and research methods. Newbury Park, CA.: Sage Publications

Ryynänen, H. - Jalkala, A. - Salminen, R. T. (2013): Supplier's Internal Communication Network During the Project Sales process. Project Management Journal, 44(3): p. 5-20.

Salminen, R. T. - Möller, K. (2006): Role of References in Business Marketing - Towards a Normative Theory of Referencing. Journal of Business-to-Business Marketing, 13(1): p. 1-15.

Schwalbe, K. (2004): Information Technology Project Management. Boston, MA.: Thomson

Skaates, M. A. - Tikkanen, H. - Lindblom, J. (2002): Relationships and project marketing success. Journal of Business \& Industrial Marketing, 17(5): p. 389-406.

Skaates, M. A. - Tikkanen, H. (2003): International project marketing: an introduction to the INPM approach. International Journal of Project Management, 21: p. 503-510.

Smith, N. J. (1995): Contract Strategy. in: Smith, N. J. (ed.): Engineering Project Management. London: Blackwell Science

Smyth, H. - Lecoeuvre, L. (2015): Differences in decision-making criteria towards the return on marketing investment: A project business perspective. International Journal of Project Management, 33: p. 29-40.

Strauss, A. - Corbin, J. M. (1998): Basics of Qualitative Research - Techniques and Procedures for Developing Grounded Theory. London: Sage

Sydow, J. - Lindkvist, L. - DeFillippi, R. (2004): Project-Based Organizations, Embeddedness and Re- positories of Knowledge: Editorial. Organization Studies, 25(9): p. 1475-1489.

Tikkanen, H. - Kujala, J. - Artto, K. (2007): The marketing strategy of a project-based firm: The Four Portfolios Framework. Industrial Marketing Management, 36(2): p. 194-205.

Turner, R. J. (2009): Farsighted project contract management. in: Turner, R. J., (ed.): Contracting for Project Management. Farnham: Gower

Turner, J. R. - Keegan, A. E. (2001): Mechanisms of governance in the project-based organisation: the role of the broker and steward. European Management Journal, 19(3): p. 254-267.

Turner, R. - Patel, K. - Lecoeuvre, L. (2012): Integrating project marketing with project management. in: European Academy of Management (EURAM) Annual Conference. Rotterdam, Netherlands

Watt, D. J. - Kayis, B. - Willey, K. (2010): The relative importance of tender evaluation and contractor selection criteria. International Journal of Project Management, 28: p. 51-60.

Webster, F. E. - Wind, Y. (1972): A General Model for Understanding Organizational Behavior. Journal of Maeketing, 36(April): p. 12-19.

Wikström, K. - Artto, K. - Kujala, J. - Söderlund, J. (2010): Business models in project business. International Journal of Project Management, 28: p. 832841.

What are PMI Certification? (n.d.): Retrieved May 15, 2015, from http://www.pmi.org/Certification/ What-are-PMI-Certifications.aspx

World Bank (2005): Little Data Book. The World Bank Development Data Book, Washington DC.

Yin, R. K. (2003): Applications of case study research. Thousand Oaks, CA.: Sage Publications 